\title{
Colloquy
}

\section{LOOKING AWAY}

\author{
LISA STEVENSON \\ McGill University \\ (iD https:/ / orcid.org/0000-0003-0705-9307
}

In the archives of McMaster University's Health Sciences Library there is a photo of a woman named Kautaq Joseph from Ikpiarjuk, Nunavut. The photo is labeled only "Eskimo 1955" and shows Kautaq sitting up in her hospital bed in the Mountain Sanatorium in Hamilton, Ontario, where she had been taken for the treatment of tuberculosis. Kautaq is wearing a printed nightgown done up right to her neck. Her straight black hair is parted on the right. Her lips are slightly open, and it is hard to know whether she is smiling or not. Both the backdrop of the photograph and the pose are familiar. Behind Kautaq are the black rungs of the hospital bed, with a series of electrical plugs above it. The pose conforms to the standard hospital mug shot that I saw over and over in the McMaster Archives: the unnamed Inuit patient photographed from the waist up, sitting or reclining in bed, taken with an eye-level camera angle and wide depth of field. In this case, Kautaq, as patient, does not look sick, only enduring and thoughtful. The only thing that distinguishes the photograph's background from the others is a partly finished strap for an amountik (a woman's parka), slung over the back of the hospital bed.

The agents responsible for the administration of the Canadian Arctic hoped that sending photographs of patients in hospital home to family members would 
lessen the trials of separation - in that sense the photographs are material evidence of the Canadian state's belated attempt to care for Inuit in hospital. But the sheer fact that hundreds of these photographs exist in a hospital archive with no identificatory markers other than labels such as "Eskimo 1955" shows them to be something else as well. Something related to the notion of an anthropological type - a concept and material artifact developed in the late 1800 s to distinguish racial groups from one another.

It is important to note that not all patients convalescing in the Mountain Sanatorium had their photos taken. The photographs, negatives, and newspaper clippings collected about Inuit were records of something extraordinary, proof of something unusual, just as an X-ray can serve as proof of tuberculosis. Not only did the Inuit patients in hospital in Hamilton harbor specimens of tuberculosis deep within their bodies but they were also — as the surfaces of their bodies made visible - specimens of another culture. And while the X-ray could expose the first form of difference (as disease), only a photograph could "expose" the latter (as ethnicity). Rather than portraits of an individual with a name and a history, the photographs seem to speak to something else. The descriptions of the negatives, contact sheets, and photographs stored in the MacMaster Archives are revealing in how little they say:

\author{
“Eskimos” 1955 \\ "Eskimos with Dr. Rabinowitz" \\ "Eskimos on Wards" Oct. 1955 \\ "Eskimos at Brow \& Grafton” May 1958
}

Each photograph of each individual Inuit stands in for a category_of "Eskimos at Brow \& Grafton,” or of “Eskimos on Wards,” or "Eskimos with Dr. Rabinowitz.”

Frantz Fanon $(2008,109)$ also described the colonial gaze using terms from the laboratory — it fixed him in place, he said, "in the sense in which a chemical solution is fixed by a dye." Describing Canadian Indigenous struggles for justice, Glen Sean Coulthard (2014) has argued that politics based in the search for recognition from the colonizer can never escape that (post)colonial circuitry of the gaze. Recognition remains in the logic of the state, the logic of categorical ways of looking. What, then, might an un-stately, unseemly, un-fixative, way of looking be? 
I find the beginning of an answer in Audra Simpson's (2014) work on refusal in Mohawk communities: in being beyond the ken of your categories, I am - and will continue to be. I find another in Michele Lancione's (2020) contribution to this issue. He writes: "Life at the margins of Bucharest, in its underground tunnels, takes its own form, its own weird assemblage: it is a life that saves itself from its own history, one that refuses institutionalization, and one that constructs its own way of being into the world - that is, its own way of dwelling, by caring for its own unfolding" (Lancione 2020, 33). And so, in what follows I want to think about what it might mean, as anthropologists, to turn or look away from our interlocutors to register something other than conceptual closure or the violence-thatis-done-through-concepts. And this way of looking has everything to do with a kind of justice that exceeds the logic of the state. It is also, I would argue, a gesture of care.

In what follows I turn to two writers, Roland Barthes and John Berger, who became interested in what we see when we close our eyes. That is, they have tried to describe ways of seeing that take into account the painful ways we are marked by history and yet still manage to see, or at least gesture to, the singularity of another being.

In Camera Lucida, Roland Barthes (1981) tells the story of searching with increasing desperation for a photograph of his mother. But he does not want just any image. He wants a "just" image. Barthes's story is really all-too famous now, and Camera Lucida has been rightly critiqued for its multiple aporias. But I want to retell the story - the story of Roland Barthes, a gay man in the 1970s finding a just picture of his mother-because it helps me imagine a way of seeing that has something to do with another, less categorical, less fixative, form of care.

Here's the story. After Barthes's mother dies, he begins to sift through old photographs looking for one that does her justice. For a while he is frustrated in the attempt - each photograph falls short in a different way. He laments that, "if I were ever to show them to friends, I doubt that these photographs would speak" (Barthes 1981, 64). But then, one day: "There I was, alone in the apartment where she had died, looking at these pictures of my mother, one by one, under the lamp, gradually moving back in time with her, looking for the truth of the face I had loved. And I found it” (Barthes 1981, 67).

The reader never gets to see that photograph of his mother. It is as if our potential inability to see what he sees in it would be too much for Barthes — would be itself a kind of injustice, and so his withholding of the photograph also is a form of self-protection. What Barthes says about the photograph he finds (he calls it the 
Winter Garden Photograph) has always struck me. He writes, "I saw the kindness which had formed her being immediately and forever. . . . Her kindness was specifically out-of-play, it belonged to no system, or at least it was located at the limits of a morality (evangelical, for instance); I could not define it better than by this feature (among others): that during the whole of our life together, she never made a single 'observation"' (Barthes 1981, 70). Barthes's Winter Garden Photograph captures something about his mother, in this case her gentleness, that cannot be reduced to any system (including our anthropological language games). It is thus not the kindness of a charitable or humanitarian impulse, nor even a maternal gesture of love. It is out-of-play. The other photographs Barthes considers "were merely analogical, provoking only her identity, not her truth; but the Winter Garden Photograph was indeed essential, it achieved for me, utopically, "the impossible science of the unique being" (Barthes 1981, 71).

What was singular about Barthes's mother, then, was this particular genre of kindness. But in a strange kind of doubling, this specific form of kindness is defined by an ability to resist generalization. That is, his mother, Barthes reports, "never made a single 'observation." (Even the simplest observation would require some sort of generalization.) No matter how literally we should take such a statement from a grieving son (that she never made observations), there was something about her ability to receive the world, rather than make observations about it, that "provokes" her truth.

Why do I want to locate a form of anthropological care in the search for a photograph that cannot be described, nor simply shown but only gestured toward? In a certain sense, of course, observations are what carry anthropological monographs along, and I would never want to do away with them. Observations are the currency of our discipline — we hope they will make the worlds we inhabit more legible and perhaps more liveable. But here I am interested in thinking about an (impossible) anthropological gesture (like Barthes's impossible science of the unique being) that erupts into our disciplinary observations, and even perhaps, language, allowing something else, something just, or something alive to temporarily break through. Perhaps we could say that it is such a gesture that could reanimate or reenchant our anthropological observations. At the very least it might upend our usual pieties.

The novelist, theorist, and painter John Berger describes such a gesture in his essay on the early nineteenth-century painter Théodore Géricault. In that essay, Berger focuses on a portrait Géricault made of a man in an asylum, diagnosed with kleptomania. In the portrait, the man is looking into the distance, looking 
elsewhere. He has tousled hair. His suffering is manifest, but so is something else, something that Berger calls beauty, but not the beauty of familiar forms and genres. Berger (2017, 209; emphasis added) writes: "Naturally the beauty he hoped to find meant turning his back on most official pieties."

Géricault made ten paintings of inmates in the same asylum where the man with kleptomania resided. Five remain. Of these portraits Berger $(2017,211)$ insists that "the way he painted them makes it clear that the last thing he was concerned with was the clinical label. His very brush marks indicate he knew and thought of them by their names. The names of their souls. The names which are no longer known.”

Thus, for Berger, seeing someone, recognizing someone, is in itself a gesture of compassion. But to recognize someone in what sense? Not to recognize their identity, Berger insists, but to understand the "name of their soul," that which has been forgotten. (Could it ever be remembered?) Barthes, as we have seen above, would call what is recognized in the faces of the inmates a kind of "truth," but it is a strange kind of truth, in that it cannot be named or categorized. We could also call it the "impossible science of the unique being."

$$
* * *
$$

It is here, around the question of looking that the differences between Berger's and Barthes's texts (one describing the search for a just photograph and one describing a painter's gaze) seem to dissolve. Because, as Berger (2017, 152-53) says more generally about portraiture, the way of looking that it requires paradoxically compels you to close your eyes and look away:

When you're trying to do a portrait of somebody else, you look very hard at them, searching to find what is there, trying to trace what has happened to the face. The result (sometimes) may be a kind of likeness, but usually, it is a dead one, because the presence of the sitter and the tight focus of observation have inhibited your response. The sitter leaves. And it can then happen that you begin again, referring not any more to a face in front of you, but to the recollected face which is now inside you. You no longer peer; you shut your eyes. You begin to make a portrait of what the sitter has left behind in your head. And now there is a chance that it will be alive.

For Berger, a portrait that has any chance at being alive is made from the traces of what the sitter has left behind in the artist's head. The artist paints with the eyes 
closed. Likewise, for Barthes, the photo that expresses the "truth" of his mother is never shown to us, though many other photos are. This play between opening and closing one's eyes, between seeing and not seeing, representability and unrepresentability, possible and impossible sciences, seems crucial to discovering a way of looking. If we are to "look in a certain way" — a way that allows us to go beyond seeing someone as a specimen from a social category, we might have to close our eyes, at least temporarily. ${ }^{2}$

So we look at the sitter of any portrait and look away. We look at the resulting image and look away. We finally find an "essential" photograph, and do not show it. Learning to look in a certain way, a way that allows us to see beyond the clinical label or social category, involves a play between seeing with our eyes and seeing with our soul — or at the very least, (if the language of soul offends) finding a way of seeing beyond the intellect and its torrent of observations. Tina Campt, writing about a series of archival passport photos of members of the Afro-Caribbean community in Birmingham, might call this "listening" to images. She writes:

To look at these images is to see genre and form. To look at them is to look through their sitters and see function and format, to "oversee" them in ways in which black people have been erased and overseen for centuries. To listen to them is to be attuned to their unsayable truths, to perceive their quiet frequencies of possibility - the possibility to inhabit a future as unbounded black subjects. (Campt 2017, 45)

This is the possibility to which an impossible science gestures.

How to look again at the portrait of Kautaq? One way might be to turn away slightly from Kautaq's face full of composure, and to look for what the photo literally sidelines: the amountik strap hanging on the corner of the bed. Unfinished, the strap resists the timeless closure of the anthropological type, or even the "homogenous, empty time" (Benjamin 1986, 261) of the clock. It indexes a moment in time when the amountik strap was precisely that far along, just as Kautaq's life was also precisely that far along. A moment with a breathless future that, in searing the photograph, is here with me as I hold the photograph in my hands - but also gone. I wonder, again, where Kautaq, looking but receding from the camera, really is or was, that day, and whether the amountik was ever finished. Unfinished, the strap disrupts the closure of the photo and puts the multiple futures - of the strap, of Kautaq's life, of my life_-into play. Through her handiwork, Kautaq sneaks out be- 
hind the designation "Eskimo 1955" and draws me ever so subtly into her world," where weaving her amountik strap must have also amounted to a gesture of hopethe hope that she would return to a place where such a strap would be needed.

\begin{abstract}
This essay turns to Roland Barthes's concept of the punctum and John Berger's writing on portraiture to describe the care involved in both anthropological encounters and ethnographic writing. It addresses how images — whether, photographic, painted, or written - may come to be seen as "just." The essay considers the possibility that it might be necessary to look away from our interlocutors, or the images we have of them, in order to be able to sense, and then communicate to others, their singularity. The traces they leave behind in our memories can allow us to register an aliveness that exceeds our existing labels, categories, and styles of thinking. [care; images; representation]
\end{abstract}

\title{
NOTES
}

1. While Fred Moten $(2003,208)$ sees Barthes's refusal to show the photo of his mother as part of a kind of "violent egocentrism," I see it as coming from his feeling that description necessarily fails to communicate singularity (as that singularity is revealed in relation to another). As he says about the punctum in Image - Music - Text, "Nothing surprising, then, if sometimes, despite its clarity, the punctum should be revealed only after the fact, when the photograph is no longer in front of me and I think back on it. I may know better a photograph I remember than a photograph I am looking at, as if direct vision oriented its language wrongly, engaging it in an effort of description which will always miss the point of its effect, the punctum" (Barthes 1977, 53).

2. Throughout his work, Berger offers an "other" way of seeing, one related to compassion. It's a way of seeing that might be learned, or at least practiced. The learning is, however, a kind of unlearning, in the sense that one lets go of, or forgets, (even for an instant) the capitalist mode of seeing that commodifies not only objects in the world but also "souls." For Berger, as a European coming of age in the postwar period, it was the capitalist desire to accumulate surplus value that defined the way his contemporaries saw the world and understood art. His response was to describe a "method" of getting beyond such a vision of the world and the people in it. In a letter he wrote to his son while the latter attended art school, he said: "To go in close means forgetting convention, reputation, reasoning, hierarchies and self. It also means risking incoherence, even madness. For it can happen that one gets too close and then the collaboration breaks down and the painter dissolves into the model" (Berger 2001, 16).

Berger wants to argue that there is a kind of "energy" behind appearances that can be seen and communicated, however imperfectly (see especially Berger 1987). To be able to communicate this energy one must let go of the moralism that is equally present in the position that every way of seeing is fully determined historically (and so I can only speak about myself when I speak about others), as well as in the (often implicit) position that one can fully know (and thus effectively govern) the other. As Berger says, for a portrait to be alive, you must register the impression (the mark, the trace) the other leaves behind when you look away. That impression is relational, it is the impression left on you, the painter or writer, but it is not reducible to you. It is your reception of the "energy" behind appearances and identities and in re-presenting it, it is possible that it will be alive. 
3. In Stolen Life, Fred Moten $(2018,92)$ asks, "Is knowledge of freedom always knowledge of the experience of freedom even when that knowledge precedes experience?" It is in this sense that I suggest that in weaving an amountik strap, Kautaq is already at home, or at least, in weaving she draws together two seemingly disparate temporalities, the hospital-present and the homecoming-future.

\section{REFERENCES}

Barthes, Roland

1977 Image — Music — Text. Essays selected and translated by Stephen Heath. New York: Hill and Wang.

1981 Camera Lucida: Reflections on Photography. New York: Hill and Wang.

Benjamin, Walter

1986 Illuminations: Essays and Reflections. Edited and with an introduction by Hannah Arendt. Translated by Harry Zohn. New York: Schocken Books.

Berger, John

1987 “A Professional Secret." New Society, December 18.

2001 The Shape of a Pocket. 1st American ed. New York: Pantheon Books.

2017 Portraits: John Berger on Artists. Edited by Tom Overton. New York: Verso.

Campt, Tina M.

2017 Listening to Images. Durham, N.C.: Duke University Press.

Coulthard, Glen Sean

2014 Red Skin, White Masks: Rejecting the Colonial Politics of Recognition. Minneapolis: University of Minnesota Press.

Fanon, Frantz

2008 Black Skin, White Masks. Translated by Charles Lam Markmann. London: Pluto. Originally published in 1952.

Lancione, Michele

2020 “Underground Inscriptions." Cultural Anthropology 35, no. 1: 31-39. https://doi.

Moten, Fred org/10.14506/ca35.1.05.

2003 In the Break: The Aesthetics of the Black Radical Tradition. Minneapolis: University of Minnesota Press.

2018 Stolen Life: Consent Not to Be a Single Being. Durham, N.C.: Duke University Press. Simpson, Audra

2014 Mohawk Interruptus: Political Life across the Borders of Settler States. Durham, N.C.: Duke University Press. 